\title{
Sustainable Development in Polish Regions: a Shift-Share Analysis
}

\author{
Iwona Cieślak ${ }^{1 *}$, Katarzyna Pawlewicz², Adam Pawlewicz ${ }^{3}$ \\ ${ }^{1}$ Institute of Geoinformation and Cartography, University of Warmia and Mazury, Olsztyn, Poland \\ ${ }^{2}$ Institute of Geography and Land Management, University of Warmia and Mazury, Olsztyn, Poland \\ ${ }^{3}$ Department of Agrotechnology, Agricultural Production Management and Agribusiness, \\ University of Warmia and Mazury, Olsztyn, Poland
}

Received: 5 September 2017

Accepted: 10 February 2018

\begin{abstract}
Sustainable development is a multi-dimensional phenomenon, and its assessment is not easy and cannot be measured and expressed by one characteristic. The authors made an attempt at designing a synthetic measure thanks to which changes in sixteen regions of Poland between 2003 and 2013 are presented with respect to the level of sustainability based on three components: social, economic, and environmental order. This enabled an analysis of the structure of sustainable development using the shift-share method. The force of impact of the internal structure was defined, along with external determinants of individual regions, which have influenced the level of sustainable development.

The performed analysis showed that the indicators of sustainable development, both for individual regions and for the whole of Poland, had not changed significantly in the determined two moments of time (2003 and 2013). However, the increase in indicators for individual regions is greatly diversified, and in the majority of provinces has a negative character with a slight value. In several regions, positive values can be noticed, whereas the increase in their values is high. This diversity testifies to the uneven development of Polish regions.
\end{abstract}

Keywords: sustainable development, integrated order, indicators of sustainable development, synthetic measure, shift-share analysis, Poland's regions

\section{Introduction}

Development is a term of utmost importance in economic sciences, both with respect to the economy and to society [1]. Here, the emphasis is placed on the significance of quantitative and qualitative changes that occur in a particular (e.g., economic or social) area. In the

*e-mail: isidor@uwm.edu.pl modern world, one of the most desired development ideas is sustainable development as a process for improving the quality of life and welfare at a level permitted by the current level of civilization [2-3].

The connecting factor among the individual areas encompassed by the sustainable development process is the integrated order, which is understood as a positive status of the target development factors, which connect, in a mutually non-contradictory and cohesive manner, component orders of the integrated order [4-6] (the 


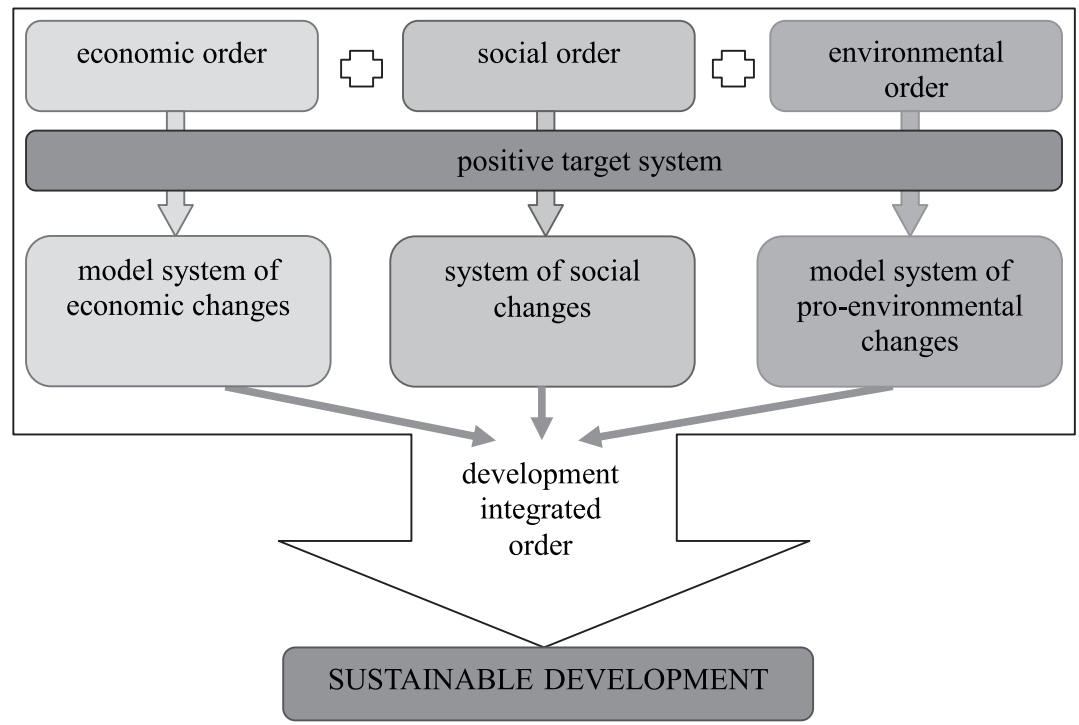

Fig. 1. Outline of sustainable development in the system of component orders (source: author's own study on the basis of Borys [5]).

integrated order is the sum of component orders). This term shows the benchmarking manner of expressing the development pattern, i.e., it is the target layout of sustainable development, and the identifying feature (a benchmark) for development changes characterised by a feature of sustainability $[5,7]$. The discussed concept may be presented in line with Fig. 1.

The basis for discussions and analyses is a thesis that sustainable development in Poland is a process with a positive direction, whereas disparities among regions are decreasing, which results in the fact that the discussed phenomenon is becoming uniform and the level of life is becoming equal. The objective of the conducted study was determining the dynamics of changes related to the level of sustainable development with respect to its components (social, economic, and environmental order) in sixteen provinces in Poland.

For the purposes of this study, the authors regard sustainable development as a process of changes encompassing the economic, social, and environmental spheres. The three spheres can mutually influence each other in positive as well as negative ways. Thus, striving for positive synergies between them represents a crucial task of sustainability-oriented decision making [8]. However, the authors regard the state of its development based on the indicators for the determined two moments of time, namely 2003 and 2013, as the level of sustainable development. The combination of all these spheres makes up the so-called integrated order. On the basis of the reference literature on this subject [9-13], the following definitions were adopted for the individual component orders:

- Economic order, understood as the capacity for economic development through generating higher incomes thanks to people's activities and enterprises.

- Social order, understood as people's capacity to improve the quality of life, to develop, and to pursue self-fulfilment.
- Environmental order, understood as the possibility for using environmental infrastructure for the purpose of utilising environmental assets and services, which would not disrupt their share in building man's welfare.

\section{Material and Methods}

As mentioned above, the assessment of sustainable development is not easy, which results from the fact that this is a multi-dimensional process that cannot be measured and expressed by a single characteristic. It unites three principal components: economic order, social order, and environmental order, which are also complex phenomena. Therefore, choosing the indicators that clearly show the problem is a particularly difficult task; what is more, they should be measurable, and the data required for them have to exist [14-15]. The feature of complexity results in the fact that the indicators are characterised with the use of synthetic variables, which enable replacing the set of multiple indicators with one value [16].

The analysis was performed in two modes: space and time. The first one refers to the static evaluation of the regions' diversity with respect to the value of indicators characterising key areas of sustainable development. In the course of study implementation, three synthetic indicators were separated, which characterise individual component orders of sustainable development for sixteen regions of Poland; they were separated through the standardisation of quantitative features (ranking method) proposed by Strahl [17]. The second mode refers to the dynamic assessment of the provinces' progress toward sustainable development, which took place in the course of a decade (2003 and 2013) and is represented by a synthetic indicator. The nature and the course of these changes were analysed using 
the shift-share analysis (SSA), which is a method applied in regional studies concerning development. It is a tool for a descriptive analysis of data, enabling the performance of in-depth studies on the nature of changes occurring in the dimensions of spatial phenomena [18]. It enables a general assessment of the efficiency of spatial phenomena with complex structures with respect to similar areas and a reference area, as well as making it possible to show the weights of specific component sectors in the entire analysed region.

SSA enables drawing conclusions with respect to the changes of phenomena in individual regions of the examined area, not only on the basis of the differences between the values of standard deviations, but also on account of the changes in the structure of such phenomena [19-20].

The classic shift-share equation for a change (increase) in the analyzed variable $\Delta x_{r i}$ in the region assumes that the increase of this variable consists of the following [21]:

- A domestic (global) part $-M_{r i}$,

- A structural part (changes in the sectoral structure) $-E_{r i}$

- A local part $-U_{r i}$

$$
\Delta x_{r i}=M_{r i}+E_{r i}+U_{r i}
$$

In summary, the classic shift-share method examines an increase or a decrease in the size of the phenomenon occurring between two moments in time, at the same time separating three components of change [22-24]:

- National (total) effect $t x_{r n e t}$, understood as the potential of the examined area, which specifies the value of the increase or the decrease of the examined phenomenon (in this case understood as a change over time in the level of sustainable development), assuming that the examined region (province) is at a similar level of development in relation to the reference area (country).

- Sectoral (structural) effect or industrial mix effect $s_{r}$, which expresses this part of the general increase and which determines the impact of changes in the structure of the examined phenomenon, i.e., the relationship between the component orders of sustainable development in the region, on its total level; a positive value indicates a more favourable structure of the phenomenon examined in the region than in the reference area.

- Regional or competitive effect, $g_{r}$, which determines the level of the so-called competitiveness of regions in the aspect of sustainable development in relation to the reference area; the value of the competitive effect indicates an increase or a decrease of the value of the synthetic variable (an aggregate measure of component orders) in the sector within the area of the examined region (province), meaning that the regional increase in the level of sustainable development may be caused by greater dynamics of component orders than in other regions.
The research for the purposes of this paper was conducted according to the following stages:

I. Analysis of reference literature on the subject with respect to the selection of features - indicators characterising individual component orders of sustainable development: economic, social, and environmental [9, 14, 25-35]. Seventeen indicators were selected for each component order, i.e., a total of 51 criteria characterising sustainable development (Table 1). When choosing variables, attention was paid to their availability and completeness. Indicators were prepared on the basis of data from the Local Data Bank of the Central Statistical Office (GUS) of Poland for the years 2003 and 2013. The indicators are listed in Table 1.

II. Standardisation of the values of features (indicators) with the use of Strahl's method [17], according to the formula below:

Stimulants:

$$
z n_{r j}=\frac{c_{r j}}{\max _{r}\left\{c_{r j}\right\}}
$$

Destimulants:

$$
z n_{r j}=\frac{\min _{r}\left\{c_{r j}\right\}}{c_{r j}}
$$

...where:

$c_{r i}$ means the values of the $j^{\text {th }}$ feature (indicator) for the $r^{\text {th }}$ object (region) $(r=1,2, \ldots, m, j=1,2, \ldots, n)$.

$z n_{r j}$ is the standardised value of the $j^{\text {th }}$ feature (indicator) for the $r^{\text {th }}$ object (region). Values of the features standardised in this manner belong to the numerical range $(0,1)$.

III. Determining synthetic indicators characterising individual component orders $\left(x_{r i}\right)$ according to the following formula:

$$
x_{r i}=\frac{1}{n} \sum_{j=1}^{n} z n_{r j}
$$

IV. Calculating the sustainable development indicators for individual regions $\left(R D_{r}\right)$ on the basis of synthetic indicators specified in point $3\left(x_{r i}\right)$, in line with the assumption that sustainable development is a total of component orders.

$$
R D_{r}=x_{e}+x_{s}+x_{e n}
$$

...where:

$x_{e}$ - synthetic variable characterising the economic order of a particular region

$x_{s}$ - synthetic variable characterising the social order of a particular region

$x_{e n}$ - synthetic variable characterising the environmental order of a particular region

$\mathrm{V}$. For the purposes of applying the shift-share analysis, increases in synthetic variables $\left(t x_{r i}\right)$, which took place 
between 2003 and 2013 for the component orders of sustainable development in individual regions, were determined.

$$
t x_{r i}=\frac{x_{r i}^{a}-x_{r i}}{x} * 100
$$

...where $r$ is the indicator corresponding to the $r^{\text {th }}$ region and the $i^{\text {th }}$ component order of sustainable development. It has to be noted that $t x_{r i}$ refers to two selected moments in time moments in time ( $a$-reference to the observation of variable $x$ in the final period) of the analysis.

VI. Determining weights of individual effects understood as the share of a selected reference variable in the total value of phenomena $z_{r i}, z_{r}$, and $z_{i}$. Assuming, in line with the reference literature on the subject [24], that the analysed phenomenon has a marginal distribution, then $z_{r i}=x_{r i}$, whereas weights, in line with the performed analyses, will adopt values resulting from the following formulas:

- Regional weights:

$$
w_{r \cdot(i)}=\frac{z_{r i}}{z_{r}}=\frac{x_{r i}}{x_{r}}
$$

- Sectoral weights:

$$
w_{\cdot i(r)}=\frac{z_{r i}}{z_{\cdot i}}=\frac{x_{r i}}{x_{\cdot i}}
$$

- Individual weights:

$$
w_{r i}=\frac{z_{r i}}{z_{. .}}=\frac{x_{r i}}{x_{. .}}
$$

...where $r=1,2, \ldots, 16 ; i$ - subsequent component order $\left(e, s\right.$, en). Sectoral weights $\left(w_{\cdot i(r)}\right)$, in line with the procedure of the shift-share analysis, were calculated for economic order $\left(x_{e}\right)$, social order $\left(x_{s}\right)$, and environmental order $\left(x_{e n}\right)$, adopting for the calculation the synthetic indicators of individual component orders in the initial period (2003) as $x_{r i}$, and the total of these indicators $\left(R D_{r}\right)$ as $x_{\cdot \cdot \cdot}$.

VII. Calculation of aggregate measures [24] applied in the shift-share analysis:

- Average growth rate in the $r$ th region:

$$
\begin{aligned}
t x_{r .}=\sum_{i} \frac{z_{r i}}{z} t x_{r i} & =\sum_{i} w_{r \cdot(i)} t x_{r i} ; \text { where } z_{r i}=x_{r i} \\
t x_{r} . & =\frac{\sum_{i=1}^{S}\left(x_{r i}^{a}-x_{r i}\right)}{\sum_{i=1}^{S} x_{r i}}
\end{aligned}
$$

- Average growth rate for variable $x$ in the $\underline{i t h}$ component of sustainable development:

$$
\begin{gathered}
t x_{\cdot i}=\sum_{r} \frac{z_{r i}}{z_{\cdot i}} t x_{r i}=\sum_{r} w_{\cdot i(r)} t x_{r i} ; \text { where } z_{r i}=x_{r i} \\
t x_{\cdot i}=\frac{\sum_{r=1}^{R}\left(x_{r i}^{a}-x_{r i}\right)}{\sum_{r=1}^{R} x_{r i}}
\end{gathered}
$$

- Average growth rate for variable $\mathrm{x}$ in the country in a particular period:

$$
\begin{array}{r}
t x_{. .}=\sum_{r=1}^{R} \sum_{i=1}^{S} \frac{z_{r i}}{z . .} t x_{r i}=\sum_{r=1}^{R} \sum_{i=1}^{S} w_{. .(r, i)} t x_{r i} ; \\
\text { where } z_{r i}=x_{r i} t x_{. .}=\frac{\sum_{r=1}^{R} \sum_{i=1}^{S}\left(x_{r i}^{a}-x_{r i}\right)}{\sum_{r=1}^{R} \sum_{i=1}^{S} x_{r i}}
\end{array}
$$

VIII. With the use of structural and geographic equality (13) resulting from the basic equation of the shiftshare analysis, a relationship (14) was determined which offers a possibility for separating the structural effect $\left(s_{r}\right)$ from the regional effect $\left(g_{r}\right)$ from the difference between the average rate of the regional growth ( and the national growth $(t x$..). The difference is the total effect $\left(t x_{\text {rnet }}\right)$ :

$t x_{r .}-t x_{. .}=\sum_{i} w_{r \cdot(i)}\left(t x_{. i}-t x_{. .}\right)+\sum_{i} w_{r \cdot(i)}\left(t x_{r i}-t x_{. i}\right)$

$$
t x_{r \text { net }}=s_{r}+g_{r}
$$

For the purposes of our study, the following effects were calculated: total, regional, and sectoral effects of the examined phenomenon for individual regions.

The regional effect was calculated with the use of the formula:

$$
g_{r}=\sum_{i} w_{r \cdot(i)}\left(t x_{r i}-t x_{\cdot i}\right)
$$

The formula for calculating the structural effect was analogously determined:

$$
s_{r}=\sum_{i} w_{r \cdot(i)}\left(t x_{\cdot i}-t x_{. .}\right)
$$

IX. Classification of the regions of Poland in terms of the level of disparity of the total, regional, and sectoral effect of sustainable development, and the preparation of maps presenting the spatial distribution of these phenomena.

Poland's regions were classified according to the data grouping method, observing the equal class ranges. In each case, three classes differentiating the level of the examined phenomena were distinguished.

\section{Results and Discussion}

The features, i.e., indicators selected in stage 1 ( for determining the levels of component orders $\left(x_{e}, x_{s}, x_{e n}\right)$ were analysed for 16 provinces of Poland. Table 1 presents data concerning the number of provinces in which, in 2003 and 2013, problems associated with the particular feature were observed. The provinces for which the value of an indicator was lower than the average value of that indicator for the country, for the stimulants, were defined as 'problem' provinces. In turn, for the destimulants, it was higher. 
Table 1. The problems of maintaining the component orders in provinces of Poland according to the indicators $\left(z n_{r j}\right)$. Source: own study

\begin{tabular}{|c|c|c|c|c|c|c|c|c|}
\hline \multirow[b]{2}{*}{ Economic order $\left(\mathrm{x}_{\mathrm{e}}\right)$} & \multicolumn{8}{|c|}{ Number of problematic* regions } \\
\hline & 2003 & 2013 & Social order $\left(\mathrm{x}_{\mathrm{s}}\right)$ & 2003 & 2013 & Environmental order $\left(\mathrm{x}_{\mathrm{en}}\right)$ & 2003 & 2013 \\
\hline $\begin{array}{l}\text { Total revenues of the county } \\
\text { per resident }(\mathrm{S})\end{array}$ & 12 & 12 & $\begin{array}{l}\text { Live births per } 1000 \\
\text { people (S) }\end{array}$ & 8 & 12 & $\begin{array}{l}\text { Surface of legally protected areas } \\
\text { as } \% \text { of the county's surface }(\mathrm{S})\end{array}$ & 10 & 10 \\
\hline $\begin{array}{l}\text { Total outlays of the county per } \\
\text { resident }(\mathrm{S})\end{array}$ & 12 & 10 & $\begin{array}{l}\text { Children in preschools } \\
\text { per } 1,000 \text { children } \\
\text { aged } 3-5(\mathrm{~S})\end{array}$ & 9 & 10 & Population density per 1 ha (D) & 5 & 6 \\
\hline $\begin{array}{l}\text { Total number of national } \\
\text { economy entities per } 1,000 \\
\text { residents }(\mathrm{S})\end{array}$ & 10 & 10 & $\begin{array}{l}\text { Gross scholarisation } \\
\text { index for primary } \\
\text { schools }(\mathrm{S})\end{array}$ & 7 & 11 & $\begin{array}{l}\text { Afforestation and restoration in the } \\
\text { total surface of the county }(\mathrm{S})\end{array}$ & 9 & 8 \\
\hline $\begin{array}{l}\text { Natural persons conducting } \\
\text { business activity per } 1,000 \\
\text { residents (S) }\end{array}$ & 9 & 9 & $\begin{array}{l}\text { Outlays on education } \\
\text { per resident }(\mathrm{S})\end{array}$ & 8 & 12 & $\begin{array}{l}\text { Surface of forests in the total } \\
\text { surface of the county (S) }\end{array}$ & 8 & 8 \\
\hline $\begin{array}{c}\text { Share of natural persons in the } \\
\text { total number of private sector } \\
\text { units (S) }\end{array}$ & 6 & 4 & $\begin{array}{l}\text { Outlays on social } \\
\text { assistance in counties } \\
\text { per resident }(\mathrm{S})\end{array}$ & 7 & 6 & $\begin{array}{l}\text { Total outlays on environmental } \\
\text { protection per resident }(\mathrm{S})\end{array}$ & 9 & 11 \\
\hline $\begin{array}{l}\text { Population of non-productive } \\
\text { age per } 100 \text { people of produc- } \\
\text { tive age (D) }\end{array}$ & 7 & 6 & $\begin{array}{l}\text { Outpatient clinics per } \\
100,000 \text { residents }(S)\end{array}$ & 9 & 6 & $\begin{array}{c}\text { Outlays on water management per } \\
\text { resident }(\mathrm{S})\end{array}$ & 10 & 9 \\
\hline $\begin{array}{l}\text { Number of working women in } \\
\text { the total number of women }(S)\end{array}$ & 8 & 11 & $\begin{array}{l}\text { Medical consultations } \\
\text { per resident }(\mathrm{S})\end{array}$ & 8 & 8 & $\begin{array}{l}\text { Consumption of grid gas per } \\
\text { resident (D) }\end{array}$ & 7 & 7 \\
\hline $\begin{array}{l}\text { Production sold per } 100 \\
\text { residents }(\mathrm{S})\end{array}$ & 12 & 11 & $\begin{array}{c}\text { Outlays on culture and } \\
\text { protection of national } \\
\text { heritage per resident } \\
\text { (S) }\end{array}$ & 10 & 10 & $\begin{array}{l}\text { Percentage of people using sewage } \\
\text { treatment plants }(\mathrm{S})\end{array}$ & 6 & 8 \\
\hline $\begin{array}{c}\text { Share of counties' outlays on } \\
\text { residential economy in total } \\
\text { outlays (S) }\end{array}$ & 9 & 11 & $\begin{array}{l}\text { Outlays on protection } \\
\text { of health per resident } \\
\text { (S) }\end{array}$ & 9 & 9 & $\begin{array}{l}\text { Share of treated sewage in sewage } \\
\text { quantity requiring treatment }(\mathrm{S})\end{array}$ & 5 & 2 \\
\hline $\begin{array}{l}\text { Hotel beds per } 1,000 \text { residents } \\
\text { (S) }\end{array}$ & 10 & 10 & $\begin{array}{l}\text { Population per library } \\
\text { (D) }\end{array}$ & 4 & 9 & Total sewage per resident (S) & 6 & 8 \\
\hline $\begin{array}{l}\text { Agricultural tax per resident } \\
\text { (S) }\end{array}$ & 6 & 6 & $\begin{array}{l}\text { Members of clubs per } \\
1,000 \text { residents }(S)\end{array}$ & 8 & 6 & $\begin{array}{l}\text { Outlays on protection of air and } \\
\text { climate per resident }(\mathrm{S})\end{array}$ & 12 & 11 \\
\hline $\begin{array}{l}\text { Length of active water supply } \\
\text { distributive network per } \mathrm{km}^{2} \\
\text { (S) }\end{array}$ & 9 & 9 & $\begin{array}{l}\text { Total accidents at } \\
\text { work per } 1000 \\
\text { workers (D) }\end{array}$ & 8 & 9 & $\begin{array}{l}\text { Percentage of residents using gas } \\
\text { grid }(\mathrm{S})\end{array}$ & 9 & 10 \\
\hline $\begin{array}{l}\text { Length of active sewage } \\
\text { system per } \mathrm{km}^{2}(\mathrm{~S})\end{array}$ & 10 & 10 & $\begin{array}{l}\text { Average length of } \\
\text { life after } 65 \text { years of } \\
\text { age }(\mathrm{S})\end{array}$ & 9 & 10 & $\begin{array}{c}\text { Surface of leisure parks managed } \\
\text { by local governments per 100,000 } \\
\text { residents (S) }\end{array}$ & 9 & 8 \\
\hline $\begin{array}{l}\text { Length of active gas system } \\
\qquad \text { per } \mathrm{km}^{2}(\mathrm{~S})\end{array}$ & 13 & 12 & $\begin{array}{l}\text { Employed people per } \\
1,000 \text { residents }(\mathrm{S})\end{array}$ & 8 & 11 & $\begin{array}{l}\text { Surface area of greenery in hous- } \\
\text { ing estates managed by local gov- } \\
\text { ernments per } 100,000 \text { residents (S) }\end{array}$ & 8 & 7 \\
\hline $\begin{array}{l}\text { Number of residents per store } \\
\text { (D) }\end{array}$ & 9 & 8 & $\begin{array}{l}\text { University students } \\
\text { per } 10,000 \text { residents } \\
\text { (S) }\end{array}$ & 12 & 11 & $\begin{array}{l}\text { Number of nature monuments per } \\
\qquad 100 \mathrm{~km}^{2}(\mathrm{~S})\end{array}$ & 7 & 7 \\
\hline $\begin{array}{l}\text { Roads with hard surface per } \\
\qquad 100 \mathrm{~km}^{2}(\mathrm{~S})\end{array}$ & 9 & 8 & $\begin{array}{l}\text { Percentage of } \\
\text { households with PCs } \\
\text { with Internet access } \\
\text { (S) }\end{array}$ & 12 & 11 & $\begin{array}{c}\text { Share of recovered waste in the } \\
\text { quantity of waste generated within } \\
\text { a year }(\mathrm{S})\end{array}$ & 11 & 8 \\
\hline $\begin{array}{l}\text { Share of recovered waste in the } \\
\text { amount of waste generated in } \\
\text { the course of the year (S) }\end{array}$ & 11 & 8 & $\begin{array}{l}\text { Average utility surface } \\
\text { of one apartment (S) }\end{array}$ & 9 & 9 & $\begin{array}{l}\text { Water consumption per resident } \\
\text { (D) }\end{array}$ & 4 & 4 \\
\hline
\end{tabular}

Designations in the table:

$\mathrm{S}$ - stimulant; D - destimulant; * indicator values in the regions were compared to the average value for the country. 
Table 2. A breakdown of synthetic indicators of component orders of sustainable development in the regions of Poland for 2003 and 2013 (source: own study).

\begin{tabular}{|c|c|c|c|c|c|c|c|c|}
\hline Poland & 0.64 & 0.63 & 0.72 & 0.73 & 0.55 & 0.56 & 1.91 & 1.92 \\
\hline \multirow{3}{*}{ Regions } & \multicolumn{6}{|c|}{ Synthetic indicators } & \multirow{2}{*}{\multicolumn{2}{|c|}{$\begin{array}{c}\text { Sustainable } \\
\text { development indicators } \\
\left(R D_{r}\right)\end{array}$}} \\
\hline & \multicolumn{2}{|c|}{$\begin{array}{c}\text { Economic order } \\
\left(x_{e}\right)\end{array}$} & \multicolumn{2}{|c|}{$\begin{array}{c}\text { Social order } \\
\left(x_{s}\right)\end{array}$} & \multicolumn{2}{|c|}{$\begin{array}{c}\text { Environmental order } \\
\left(x_{e n}\right)\end{array}$} & & \\
\hline & 2003 & 2013 & 2003 & 2013 & 2003 & 2013 & 2003 & 2013 \\
\hline Dolnośląskie & 0.69 & 0.67 & 0.70 & 0.72 & 0.63 & 0.57 & 2.02 & 1.96 \\
\hline Kujawsko-Pomorskie & 0.63 & 0.59 & 0.76 & 0.73 & 0.56 & 0.56 & 1.95 & 1.88 \\
\hline Lubelskie & 0.58 & 0.54 & 0.75 & 0.75 & 0.54 & 0.53 & 1.87 & 1.82 \\
\hline Lubuskie & 0.59 & 0.59 & 0.76 & 0.78 & 0.66 & 0.62 & 2.01 & 1.99 \\
\hline Lódzkie & 0.63 & 0.61 & 0.77 & 0.77 & 0.61 & 0.59 & 2.01 & 1.97 \\
\hline Małopolskie & 0.72 & 0.73 & 0.76 & 0.77 & 0.59 & 0.66 & 2.08 & 2.16 \\
\hline Mazowieckie & 0.65 & 0.70 & 0.71 & 0.74 & 0.51 & 0.53 & 1.87 & 1.97 \\
\hline Opolskie & 0.61 & 0.61 & 0.71 & 0.71 & 0.52 & 0.61 & 1.84 & 1.92 \\
\hline Podkarpackie & 0.61 & 0.62 & 0.72 & 0.80 & 0.59 & 0.62 & 1.91 & 2.04 \\
\hline Podlaskie & 0.53 & 0.54 & 0.78 & 0.74 & 0.65 & 0.66 & 1.97 & 1.95 \\
\hline Pomorskie & 0.66 & 0.67 & 0.69 & 0.70 & 0.55 & 0.61 & 1.91 & 1.98 \\
\hline Śląskie & 0.84 & 0.81 & 0.72 & 0.74 & 0.60 & 0.63 & 2.16 & 2.18 \\
\hline Świętokrzyskie & 0.58 & 0.59 & 0.67 & 0.72 & 0.55 & 0.61 & 1.80 & 1.91 \\
\hline Warmińsko-Mazurskie & 0.60 & 0.58 & 0.73 & 0.71 & 0.63 & 0.64 & 1.95 & 1.93 \\
\hline Wielkopolskie & 0.64 & 0.61 & 0.69 & 0.71 & 0.48 & 0.47 & 1.81 & 1.79 \\
\hline Zachodniopomorskie & 0.64 & 0.64 & 0.74 & 0.68 & 0.46 & 0.51 & 1.83 & 1.83 \\
\hline
\end{tabular}

Many provinces in Poland struggle with numerous problems of maintaining the component orders. The fewest provinces with problems were identified for the environmental order indicators, while the most were for the economic order in 2003, and for the social order in 2013. It should be noted, however, that within the economic order $(x)$ in 2013 , as compared to 2003 , the number of provinces with problems only increased for: Number of working women in the total number of women - o 3, Share of counties' outlays on residential economy in total outlays $-\mathrm{o} 2$. In turn, within the social order $(\mathrm{x})$, the number of provinces with problems increased for as many as eight indicators of this order, the most for the Population per library - by as many as 5 provinces. Within the environmental order $\left(x_{e n}\right)$ for 5 indicators, the number of problem provinces also increased in 2013 as compared to 2003. These were the following indicators: Total outlays on environmental protection per resident, Percentage of people using sewage treatment plants, Total sewage per resident - an increase by 2 problem provinces, and for the indicators of Population density per 1 ha, Percentage of residents using gas grid, an increase by 1 .

All provinces were ranked with respect to the level of maintenance of individual component orders of sustainable development (economic, social, and environmental) in two periods of 2003 and 2013 through the standardisation of the values of features (indicators) - stage 2. Synthetic indicators $\left(x_{e}, x_{s}, x_{e n}\right)$ were analogously determined for the entire country - stage 3 . The results are presented in Table 2.

The indicators calculated in this manner were used for analyzing changes occurring in the level of sustainable development in the regions of Poland in accordance with the procedure presented in stages 4-9. The results of the calculations are presented in Table 3.

While interpreting the results of the analysis, it is worth noting that the sustainable development indicators, with respect to both the regions and the entire country, did not change greatly in the determined two moments of time (2003 and 2013). The average growth rate for the regions ranged from -3.59 to 6.67 . In the majority of provinces, the growth rate has negative values, whereas for the entire country it only amounted to 0.52 . This is an unsatisfactory result if one takes into account the fact of Poland's accession to the European Union during the period concerned, and the implementation, in the course of these ten years, of many programs supporting sustainable development of regions and increasing their economic, social, and environmental cohesion. In this light, the decrease in the value of indicators for the majority of provinces is rather surprising. 
Table 3. A breakdown of the results of the shift-share analysis for the components of sustainable development in the regions of Poland (source: own study).

\begin{tabular}{|c|c|c|c|c|c|c|c|c|c|c|c|c|}
\hline \multirow{2}{*}{ No. } & \multirow{2}{*}{ Regions } & \multicolumn{3}{|c|}{ Sectoral weights } & \multirow{2}{*}{$w_{r}$} & \multicolumn{3}{|c|}{$\begin{array}{c}\text { Growth of synthetic } \\
\text { variables }\end{array}$} & \multirow{2}{*}{$\begin{array}{c}\text { Sverage growth rate } \\
\text { in the } r^{\text {th }} \text { region } \\
t x_{r} .\end{array}$} & \multicolumn{3}{|c|}{ Effects } \\
\hline & & $w_{r e}$ & $w_{r s}$ & $w_{r e n}$ & & $t x_{r e}$ & $t x_{r s}$ & $t x_{r e n}$ & & tx $x_{\text {rnetto }}$ & $s_{r}$ & $g_{r}$ \\
\hline 1 & Dolnośląskie & 0.34 & 0.35 & 0.31 & 1.06 & -2.90 & 2.86 & -9.52 & -2.97 & -3.49 & -0.01 & -3.48 \\
\hline 2 & Kujawsko-Pomorskie & 0.32 & 0.39 & 0.29 & 0.97 & -6.35 & -3.95 & 0.00 & -3.59 & -4.11 & 0.04 & -4.15 \\
\hline 3 & Lubelskie & 0.31 & 0.40 & 0.29 & 0.96 & -6.90 & 0.00 & -1.85 & -2.67 & -3.20 & 0.07 & -3.27 \\
\hline 4 & Lubuskie & 0.29 & 0.38 & 0.33 & 1.07 & 0.00 & 2.63 & -6.06 & -1.00 & -1.52 & 0.14 & -1.66 \\
\hline 5 & Łódzkie & 0.31 & 0.38 & 0.30 & 1.00 & -3.17 & 0.00 & -3.28 & -1.99 & -2.51 & 0.07 & -2.58 \\
\hline 6 & Małopolskie & 0.35 & 0.37 & 0.28 & 1.03 & 1.39 & 1.32 & 11.86 & 4.33 & 3.80 & -0.04 & 3.84 \\
\hline 7 & Mazowieckie & 0.35 & 0.38 & 0.27 & 0.90 & 7.69 & 4.23 & 3.92 & 5.35 & 4.82 & -0.04 & 4.87 \\
\hline 8 & Opolskie & 0.33 & 0.39 & 0.28 & 0.98 & 0.00 & 0.00 & 17.31 & 4.89 & 4.37 & 0.01 & 4.36 \\
\hline 9 & Podkarpackie & 0.32 & 0.38 & 0.31 & 1.04 & 1.64 & 11.11 & 5.08 & 6.28 & 5.76 & 0.06 & 5.70 \\
\hline 10 & Podlaskie & 0.27 & 0.40 & 0.33 & 1.02 & 1.89 & -5.13 & 1.54 & -1.02 & -1.54 & 0.21 & -1.74 \\
\hline 11 & Pomorskie & 0.35 & 0.36 & 0.29 & 0.97 & 1.52 & 1.45 & 10.91 & 4.19 & 3.66 & -0.04 & 3.70 \\
\hline 12 & Śląskie & 0.39 & 0.33 & 0.28 & 1.14 & -3.57 & 2.78 & 5.00 & 0.93 & 0.40 & -0.16 & 0.57 \\
\hline 13 & Świętokrzyskie & 0.32 & 0.37 & 0.31 & 0.83 & 1.72 & 7.46 & 10.91 & 6.67 & 6.14 & 0.05 & 6.10 \\
\hline 14 & $\begin{array}{l}\text { Warmińsko- } \\
\text { Mazurskie }\end{array}$ & 0.31 & 0.37 & 0.32 & 1.09 & -3.33 & -2.74 & 1.59 & -1.54 & -2.06 & 0.10 & -2.17 \\
\hline 15 & Wielkopolskie & 0.35 & 0.38 & 0.27 & 0.92 & -4.69 & 2.90 & -2.08 & -1.10 & -1.63 & -0.06 & -1.56 \\
\hline 16 & Zachodniopomorskie & 0.35 & 0.40 & 0.25 & 1.02 & 0.00 & -8.11 & 10.87 & -0.55 & -1.07 & -0.05 & -1.02 \\
\hline & Poland & 0.34 & 0.38 & 0.29 & & & & $t x$ & 0.52 & & & \\
\hline & $t x_{\cdot i}$ & -1.56 & 1.39 & 1.82 & & & & & & & & \\
\hline
\end{tabular}

Designations in the table: $\mathrm{r}=1,2, \ldots, 16$; e, $\mathrm{s}$, en - subsequent component order

$\mathrm{w}_{\mathrm{r}}$ - regional weight; $\mathrm{tx}_{\text {rnetto }}$ - total effect; $\mathrm{s}_{\mathrm{r}}-$ sectoral effect; $\mathrm{g}_{\mathrm{r}}-$ regional effect; $\mathrm{tx}$ - average growth rate of sustainable development for the country; $\mathrm{tx}_{\mathrm{i}}$ - average growth rate of individual components in the country.

Source: own study

Regions develop non-uniformly, showing an accrual decrease in nine cases, while in seven cases there was an accrual increase. The lowest negative growth rates were recorded in Kujawsko-Pomorskie (-3.59), Dolnośląskie (-2.97), and Lubuskie Provinces (-2.67); the negative growth rates was slightly lower in Łódzkie Province (-1.99) and in Warmińsko-Mazurskie Province (-1.54). The lowest negative growth rates were caused by the decrease in the values of principal components in particular provinces $\left(t x_{r i}\right)$. In Kujawsko-Pomorskie Province, it was a decrease in the value of the indicator of the economic (noted at a level of -0.4) and social order $(-0.3)$, in Dolnośląskie Province the environmental (-0.6) and economic order $(-0.4)$, in Lubuskie Province the environmental (-0.4), in Łódzkie Province the economic and environmental order (-0.3), and in WarmińskoMazurskie the economic and social order ( -0.2 each). For certain provinces, an accrual increase in indicators can be noticed, which testifies to a higher rate of positive changes toward sustainable development compared to other regions of the country. Such dynamics of changes can be noted in particular in Świętokrzyskie (6.67), Podkarpackie (6.28), and Mazowieckie provinces (5.35). Such large increases in the indicators in these provinces were due to an increase in the values of primarily the components of the social $\left(t x_{r s}\right)$ and environmental order $\left(t x_{r e n}\right)$ and, to a lesser degree, of the economic order $\left(t x_{r e}\right)$. For Świętokrzyskie Province, there were increases at a level of 0.5, 0.6, and 0.1, respectively; for Podkarpackie Province 0.8, 0.3, and 0.1; and for Mazowieckie Province, $0.3,0.2$, and 0.5 . In spite of the fact that the fluctuations of increases (taking into account their minimum and maximum values) for all regions are not significant, as they only amount to 10.26 , the diversity of trends of these increases is quite surprising.

After taking into account the sectoral weights $\left(w_{r i}\right)$ of particular orders in the final indicator of sustainable development (Table 3), and after comparing the total effects with the increase in this indicator for the country, the provinces were classified in accordance with the value of this difference. Spatial diversity in the distribution of the total effect in Polish regions divided by classes, 
distinguished in line with the above-described procedure, is presented in Fig. 2. Six provinces showed the total effect which positioned them in class I, i.e., from 6.14 to 2.73 . This testifies to the great potential of these provinces, and to the above-average increase in sustainable development indicators for these provinces: Opolskie, Pomorskie, Mazowieckie, Świętokrzyskie, Małopolskie, and Podkarpackie. For all these provinces, increases in the principal components $\left(t x_{r i}\right)$ at a level $>=0,00$ are observed, with the largest ones for the environmental sector $\left(t x_{r s}\right)$. This is significant as this is exactly for this sector that the lowest sectoral weights $\left(w_{\text {ren }}\right)$ ranging from 0.27 to 0.31 are observed, which means that the value of the indicator $R D r$ was affected the most in 2003 by the environmental order. Therefore, this is a good direction of change, which, for most provinces in this class, resulted in a high total effect. Class II comprises regions for which the growth rate was similar to the national one (the total effect ranges from 2.72 to -0.68). Only Śląskie Province is included in this class. In as many as eight cases, the total effect turned out to be much smaller than the average growth rate in the country - this is class III (from - 0.69 to -4.11), and it mainly encompassed the regions of central and western Poland - Lubuskie, Dolnośląskie, Wielkopolskie, Kujawsko-Pomorskie, Łódzkie, and Zachodniopomorskie - and a strip of eastern regions, i.e., Lubelskie, Warmińsko-Mazurskie, and Podlaskie provinces. The provinces included in this class show a much lower potential of the development of the phenomena identified with sustainable development than the potential of the country. The increases in all components $\left(t x_{r i}\right)$ for these provinces are either negative or fluctuate around zero. The greatest negative increases are observed for the economic order $\left(t x_{r e}\right)$.

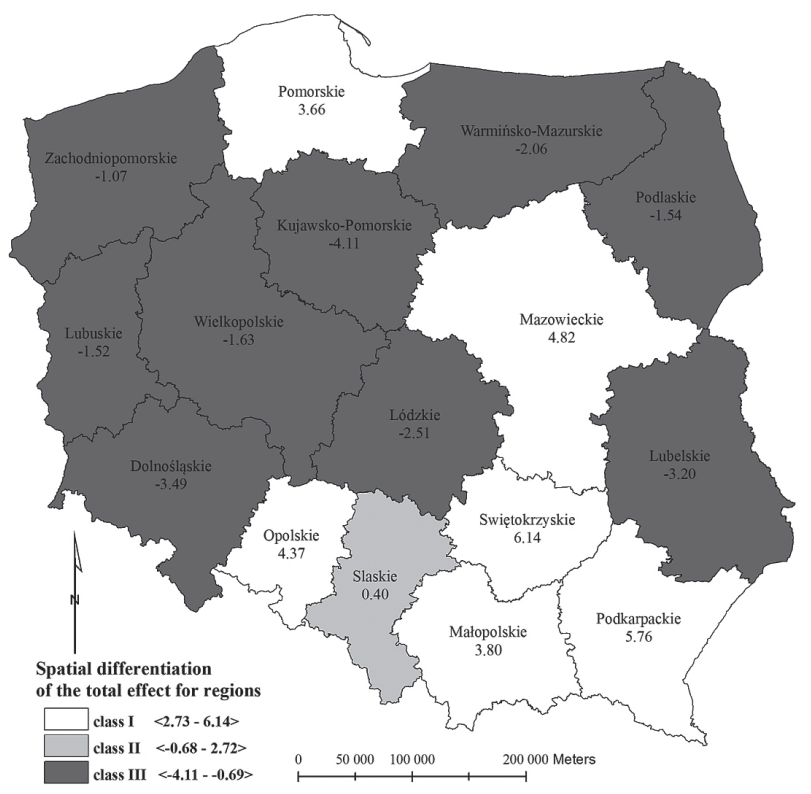

Fig. 2. Map of spatial differentiation of the total effect for individual regions of Poland divided into classes (source: own study).
While searching for the causes of the phenomenon being thus shaped, the results obtained for the sectoral effect and the regional effect for changes in the level of sustainable development in the years 2003 and 2013 were analysed. On the basis of the results we can ascertain that the growth rates for regions were slightly affected by the internal structure of the sustainable development components. The sectoral weights for all components $\left(w_{r i}\right)$ range slightly from 0.25 to 0.40 . Sectoral effects calculated for individual provinces show a relative balance of factors. Taking into account the fact that the study refers to sustainable development, this is a positive phenomenon testifying to the homeostasis in the relationship between component orders. The values for this effect range from the level of -0.16 for Śląskie Province to 0.21 for Podlaskie Province. The classification of provinces on account of the sectoral effect is presented in Figure 3. Class I comprises provinces where the structure of orders had the greatest impact on the increase in the total effect of the phenomenon. These were the provinces for which the value of the sectoral effect $\left(s_{r}\right)$ ranged from 0.21 to 0.10 , namely Podlaskie, Lubuskie, and Warmińsko-Mazurskie provinces. This means that in these provinces, the internal balance of the component orders increased. Class II comprises regions in which this impact was slight (from 0.03 to 0.09). This class includes Opolskie, KujawskoPomorskie, Świętokrzyskie, Podkarpackie, Lubelskie, and Łódzkie. On the other hand, class III encompasses regions in which the structure of component orders decreased the level of sustainable development (the $s_{r}$ values from -0.16 to -0.04): Śląskie, Wielkopolskie, Dolnośląskie, Zachodniopomorskie, Mazowieckie, Małopolskie, and Pomorskie. For these provinces, the

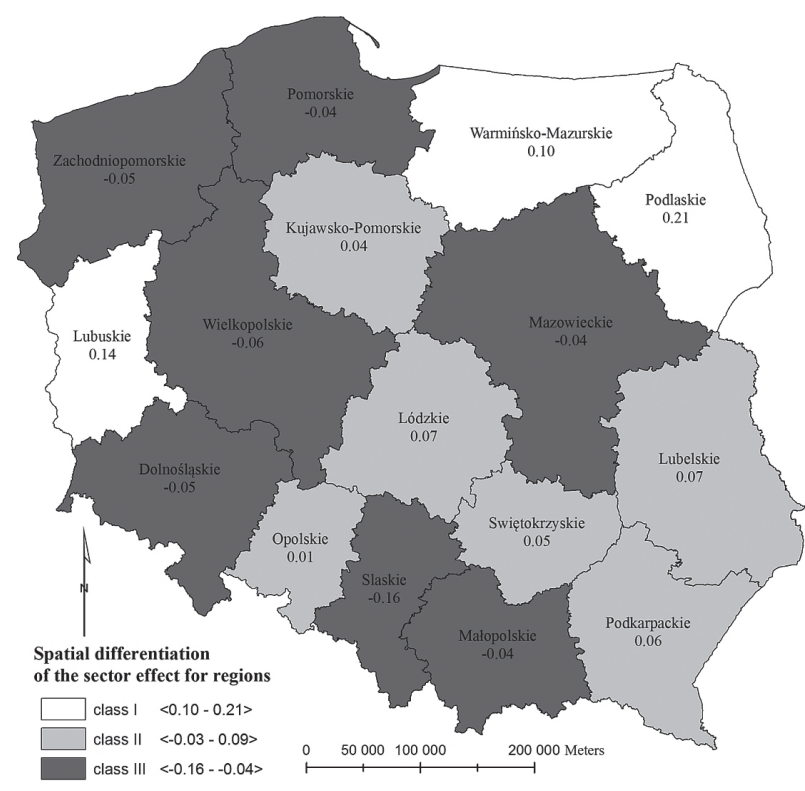

Fig. 3. Map of spatial differentiation of the sectoral effect for individual regions of Poland divided into classes (source: own study). 
internal balance of the orders in 2003-2013 was disturbed the most. It should be remembered, however, that the values of the structural effect $\left(s_{r}\right)$ for all provinces were not high.

The rate of development of individual regions is predominantly influenced by competitiveness in relation to other regions. The regional (competitiveness) effect ranges quite significantly from 6.10 for Świętokrzyskie Province to -4.15 for Kujawsko-Pomorskie Province, which confirms the increasing disparities between individual provinces, and contradicts the efforts aimed at the territorial cohesion of regions. The spatial differentiation of the discussed effect as well as the classification is presented in Fig. 4.

Class I includes six provinces for which the regional effect ranged from 6.10 to 2.69. These were provinces in which the increase in the level of sustainable development was caused in particular by the strongly increased dynamics of component orders in comparison to other regions of the country. These were the following provinces: Świętokrzyskie, Podkarpackie, Mazowieckie, Opolskie, and Pomorskie. In these provinces, the increase in the $R D_{r}$ indicator, as compared to other provinces, was the largest. Class II (from 2.68 to -0.72) includes provinces in which the regional effect showed their average competitiveness in relation to other provinces. These were Podlaskie and Śląskie, whereas class III (from -0.73 to -4.15 ) encompasses provinces where the dynamics of the development of component orders was lower than in other provinces. This class includes Kujawsko-Pomorskie, Dolnośląskie, Lubelskie, Łódzkie, Warmińsko-Mazurskie, Lubuskie, Wielkopolskie, and Zachodniopomorskie. For these provinces, the $R D_{r}$ indicator and the increases $\left(t x_{r}\right)$ in this indicator in

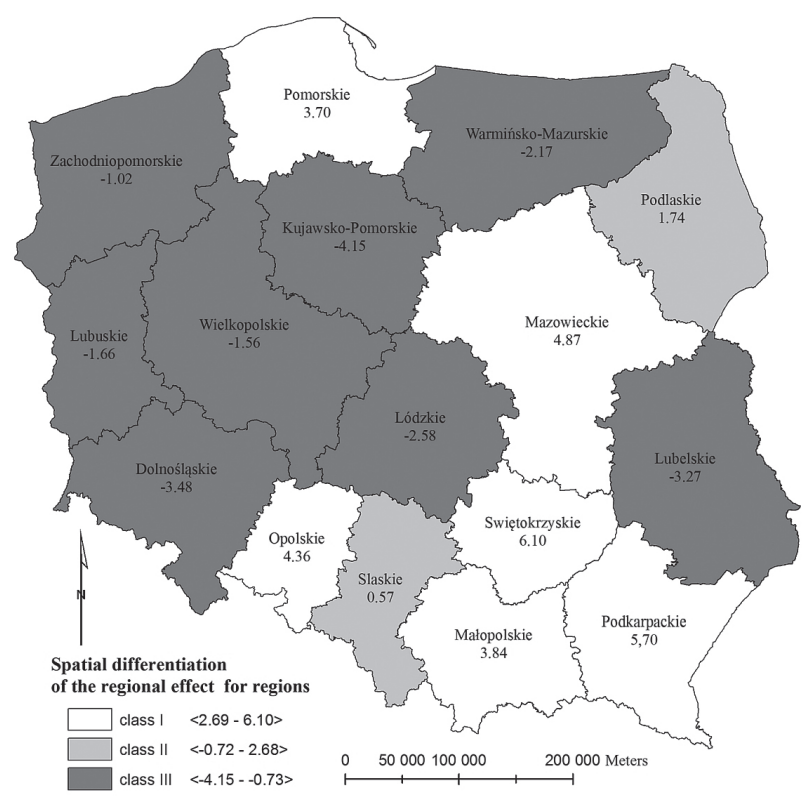

Fig. 4. Map of the spatial differentiation of the regional effect for individual regions of Poland divided into classes (source: own study).
2003-2013 were lower than the average values for other provinces.

The main objective of the idea of sustainable development is to improve the quality of life of the society by ensuring good living conditions and the transformation of social values. The authors presented an attempt at comparing the level and the evaluation of progress made by regions in Poland in the area of sustainable development in 2003 and 2013, using indicators and statistical analysis. This enabled designing a synthetic measure that provided a basis for discussing changes in sixteen regions of Poland with respect to the level of sustainability on the basis of the components, namely social order, economic order, and environmental order, as well as classifying them into a group of regions with similar levels of the examined phenomenon. Such an approach offered a possibility for analysing the structure of sustainable development with the use of the shift-share method. The results of this analysis enabled the determination of the power of impact of the internal structure and external determinants of individual regions, which had direct impact on the level of sustainable development.

When interpreting the results of the performed analysis, it is worth noting that the sustainable development indicators $\left(R D_{r}\right)$, with respect to both the regions and the entire country, did not change significantly in two analysed points in time (2003 and 2013). It has to be emphasized that increases in the discussed indicators $\left(t x_{r}\right)$ for individual regions are greatly diversified. However, in the majority of provinces the average growth rate $\left(t x_{r}\right)$ has a negative value, and only in some cases can their positive values be noticed. Even though the accrual decreases take low values, in regions with an accrual increase the value is several times higher. This diversity also testifies to the fact that Polish regions are not developing uniformly. This is confirmed by the detailed analysis of the effects of the examined phenomenon. The total effects $\left(t x_{n e t}\right)$ take values similar to the average growth rate for sustainable development. The growth rate for regions was slightly influenced by the internal structure of components. This is confirmed by the results obtained for sectoral effects $\left(s_{r}\right)$ calculated for individual provinces, which show a relative balance of factors. Taking into account the fact that the studies refer to sustainable development, this is a positive phenomenon testifying to an equilibrium in relations among component orders. Competitiveness in relation to other regions, manifested in the regional effects (competitiveness) $\left(g_{r}\right)$, had a major impact on the increased level in individual regions. Their values differ greatly, which means that the regions differ between one another in terms of the determinants of sustainable development. 


\section{Conclusions}

The conducted study fulfils its main aim. The presented method offered an opportunity to determine the dynamics of sustainable development of the provinces of Poland, and specified which elements of this phenomenon determine these changes. An analysis of the level of balance between the component orders of sustainable development and a comparison of this development to its state in Poland and in other provinces were the outcome of the performed analysis. This outcome contributes to the scientific and objective evaluation of regional ecological construction of civilisation in order to make proper decisions and take proper actions.

An analysis of the indicators of sustainable development allows for the conclusion that in regions of Poland, many problems within all component orders, with a slightly lower intensity in the environmental order, can be noticed. The level of particular orders is primarily adversely affected by problems resulting from an insufficient budget of local government units, which is manifested by the under-financing of many areas under development, i.e., health protection, education, upbringing, culture, the protection of national heritage, environmental protection, water management, the air, and housing management. As regards other problems faced by the regions of Poland, low professional activity and economic activity of the inhabitants as well as demographic problems associated with a decrease in the number of children born and in the average life expectancy after having reached 65 years of age can be indicated. There are also shortages in the infrastructural development and the education of the society, and the lifestyles of inhabitants, which is indicated by the small average usable floor space of flats, low percentage of households with a personal computer with Internet access, and the large number of people per library.

A shift-share analysis of sustainable development in Poland confirmed the main thesis of the study, according to which this is a process with a positive direction, yet the disparities between regions are not getting smaller, and the levels of life are becoming equal not as quickly as expected. Given that the study concerns changes to this phenomenon in 2003-2013, it appears that they occur too slowly and unevenly in all regions. This is indicated by the values of increases in the $t x_{r i}$ phenomenon and in the values of total effects calculated for the provinces $t x_{n e t t o}$ as well as the sectoral $s_{r}$ and regional $g_{r}$ effects.

The performed analysis confirms the suitability of the applied procedure and of the method for investigating the phenomenon of sustainable development on a regional scale. It helps to perceive sustainable development as an actual balance between economic, environmental, and social orders in dynamic terms. It is of exceptional importance as it is closely related to the fundamental assumptions of sustainable development.

\section{Conflict of Interest}

The authors declare no conflict of interest.

\section{References}

1. SOLÁR J., JANIGA M., MARKULJAKOVÁ K. The Socioeconomic and Environmental Effects of Sustainable Development in the Eastern Carpathians, and Protecting its Environment. Polish Journal of Environmental Studies, 25 (1), 291, 2016.

2. ULFIK A., NOWAK S. Determinants of Municipal Waste Management in Sustainable Development of Regions in Poland. Polish Journal of Environmental Studies, 23 (3), 1039, 2014

3. EMAS R. The concept of sustainable development: definition and defining principles. Florida International University. 2015.

4. Act on the Protection and Management of Environment of $31^{\text {st }}$ January, 1980 as published in Journal of Laws 1994 No. 49, item 196 [In Polish].

5. BORYS T. Sustainable Development - How to Recognize Integrated Order. Problemy Ekorozwoju, 6 (2), 75, 2011 [In Polish].

6. JAŃCZUK L. Local government as the benchmark of integrated governance in the process of sustainable development. Prace Naukowe Uniwersytetu Ekonomicznego we Wrocławiu, 391, 248, 2015 [In Polish].

7. CHODKOWSKA-MISZCZUK J. Small-scale renewable energy systems in the development of distributed generation in Poland. Moravian Geographical Reports, 22 (2), 34, 2014.

8. HANSMANN R., MIEG H.A., FRISCHKNECHT P. Principal sustainability components: empirical analysis of synergies between the three pillars of sustainability. International Journal of Sustainable Development \& World Ecology, 19 (5), 451, 2012.

9. BORYS T. Design and test of the methodological framework and the procedures for self-assessment of gminas on the basis of indicators of sustainable development in the Local Government Analysis System (SAS) 23. Available online: $\quad$ www.sas.zmp.poznan.pl/informacje/grupyporownawcze-z3.pdf (cit. 16.01.2017), 2008.

10. ADAMOWICZ M., SMARZEWSKA A. Model and indicators of sustainable development in rural areas from the local perspective. Zeszyty Naukowe Polityki Europejskie, Finanse i Marketing, SGGW w Warszawie, 1 (50), 251, 2009 [In Polish].

11. MIERZEJEWSKA L. Sustainable development of the City. Cognitive and practical issues, Publisher: UAM. Poznań, Poland, 2010 [In Polish].

12. DEMPSEY N., BRAMLEY G., POWER S., BROWN C. The social dimension of sustainable development: Defining urban social sustainability. Sustainable Development, 19 (5), 289, 2011.

13. BURJA C., BURJA V. Sustainable development of rural areas: a challenge for Romania. Environmental Engineering \& Management Journal (EEMJ), 13 (8). 2014.

14. CHOON S-W., SIWAR CH., PEREIRA J.J., JEMAIN A.A., HASHIM H.S., HADI A.S. A sustainable city index for Malaysia. International Journal of Sustainable Development \& World Ecology, 18 (1), 28, 2011.

15. PURVIS M., GRAINGER A. (Eds.). Exploring sustainable development: Geographical perspectives. Routledge. 2013. 
16. PÉREZ A.G., LÓPEZ M.H., ECHEVERRÍA F.R. Sustainable Development Synthetic Indicators Based on Distance for Venezuela. In Mechanics, Energy, Environment, Bulucea A., Energy, Environmental and Structural Engineering Series, 42, WSEAS Press: Rome, Italy, 194, 2015.

17. STRAHL D. Econometric methods to program development of the industry., Publisher: AE, Wrocław, Poland, 1984 [In Polish].

18. GOSCHIN Z. Regional growth in Romania after its accession to EU: a shift share analysis approach. Emerging Markets Queries in Finance and Business. Procedia Economics and Finance, 15, 169, 2014.

19. HERATH J., GEBREMEDHIN T.G., MAUMBE B.M. A dynamic shift-share analysis of economic growth in West Virginia. Journal of Rural and Community Development, 6 (2), 155. 2011.

20. KARLSSON C., ANDERSSON M., NORMAN T. (Eds.). Handbook of Research Methods and Applications in Economic Geography. Edward Elgar Publishing. 2015.

21. STIMSON R. (Ed.). Handbook of research methods and applications in spatially integrated social science. Edward Elgar Publishing. 2014.

22. BLAIR J.P., CARROLL M. Local Economic Development: Analysis, Practices, and Globalization. 2009.

23. JIYING W., XICANG Z. Application of the Spatial Shiftshare Analysis [J]. Statistical Research, 4, 013, 2009.

24. SUCHECKI B. Spatial Econometrics. Methods and models of analysis of spatial data, Publisher: C.H. Beck, Warszawa, Poland, 2010 [In Polish].

25. MASCARENHAS A., COELHO P., SUBTIL E., RAMOS T.B. The role of common local indicators in regional sustainability assessment. Ecological Indicators, 10 (3), 646, 2010.
26. BRODZIŃSKI Z. Stimulating of Rural Development at the locallevel on the example the Warmińsko-Mazurskie voivodship, Publisher: SGGW, Warszawa, Poland, 2011.

27. DAHL A.L. Achievements and gaps in indicators for sustainability. Ecological Indicators, 17, 14, 2012.

28. KUIK O.J., VERBRUGGEN H. (Eds.). In search of indicators of sustainable development (Vol. 1). Springer Science \& Business Media. 2012.

29. SINGH R.K., MURTY H.R., GUPTA S.K. DIKSHIT A.K. An overview of sustainability assessment methodologies, Ecological Indicators, 15 (1), 281, 2012.

30. RINNE J., LYYTIMÄKI J., KAUTTO P. From sustainability to well-being: Lessons learned from the use of sustainable development indicators at national and $\mathrm{EU}$ level. Ecological Indicators, 35, 35, 2013.

31. TURCU C. Re-thinking sustainability indicators: local perspectives of urban sustainability. Journal of Environmental Planning and Management, 56 (5), 695. 2013.

32. BURCHARD-DZIUBIŃSKA M., RZEŃCA A., DRZAZGA D. Sustainable development: natural choice. Publisher of the University of Lodz. 2014 [In Polish].

33. ENDERS J.C., REMIG M. (Eds.). Theories of sustainable development. Routledge. 2014.

34. PAWLEWICZ K. Differences in development levels of urban gminas in the Warmińsko-Mazurskie voivodship in view of the main components of sustainable development. Bulletin of Geography. Socioeconomic Series, 29, 93, 2015.

35. PAWLEWICZ K., PAWLEWICZ A., CIEŚLAK I. Evaluation of the Implementation of Sustainable Development in Rural Communes in Eastern Poland. Economic Science for Rural Development: Rural Development and Entrepreneurship; Bioeconomy; Home Economics, 41, 132, 2016. 
